\title{
Optimization using central composite design (CCD) of response surface methodology (RSM) for biosorption of hexavalent chromium from aqueous media
}

\author{
Jonas Bayuo $^{1}$ (D) Moses Abdullai Abukari ${ }^{2} \cdot$ Kenneth Bayetimani Pelig-Ba ${ }^{1}$
}

Received: 31 July 2019 / Accepted: 28 April 2020 / Published online: 12 May 2020

(C) The Author(s) 2020

\begin{abstract}
In this study, unmodified biosorbent was obtained from Arachis hypogea husk and applied to remove hexavalent chromium $[\mathrm{Cr}(\mathrm{VI})]$ from aqueous media through batch technique. The independent variables (contact time, $\mathrm{pH}$ of the solution and initial $\mathrm{Cr}(\mathrm{VI})$ concentration) influencing the adsorption process were optimized by central composite design (CCD) found in response surface methodology of the Design-Expert software 12.0.0 at a fixed temperature of $30 \pm 0.5^{\circ} \mathrm{C}$. Furthermore, equilibrium sorption isotherms and kinetics studies were also investigated. The ANOVA component of the CCD indicated that all the process independent variables investigated had significant impacts on the sorption capacity of $\mathrm{Cr}(\mathrm{VI})$ by Arachis hypogea husk. The obtained experimental data showed that at the optimized 120 min contact time, $8.0 \mathrm{pH}$ of the aqueous solution and $50 \mathrm{mg} / \mathrm{L}$ initial $\mathrm{Cr}(\mathrm{VI})$ concentration resulted in an optimum adsorption capacity of $2.355 \mathrm{mg} / \mathrm{g}$. Equilibrium sorption isotherm and kinetic studies showed that Redlich-Peterson adsorption isotherm and pseudo-second-order kinetic models fitted well to the equilibrium data. The unmodified adsorbent from Arachis hypogea husk was found to be efficient for $\mathrm{Cr}(\mathrm{VI})$ decontamination from the aqueous media.
\end{abstract}

Keywords Biosorption $\cdot$ Equilibrium $\cdot$ Hexavalent chromium $\cdot$ Model $\cdot$ Process optimization

\section{Introduction}

Toxic heavy metals are often released into the ecosystem through agricultural and industrial activities and spread into the natural environment, and their presence in the environment may be harmful to people, plants and animals. These inorganic micro-pollutants are nonbiodegradable, extremely toxic and have a carcinogenic consequence and other healthrelated problems (Cimino et al. 2000). Heavy metal ions are present in the biosphere and industrial wastewater and owing to their kinesis in the aquatic environment and toxicity; their presence in water media had turned out to be a main inorganic pollution problem. Discharge and treatment of

Jonas Bayuo

jonas87bayuo@yahoo.com

1 Department of Applied Chemistry and Biochemistry, University for Development Studies, Postal Box 24, Navrongo Campus, Ghana

2 Department of Science and Mathematics Education, University for Development Studies, Postal Box 24, Navrongo Campus, Ghana aqueous solution containing poisonous metals and specific identification of the main sources of their pollution of water resources are imperative, because the acute, severe and persistent effects of these contaminants on the health of living species and on the sustainability of ecosystems are essential concerns in environmental protection (Bayuo et al. 2018).

Chromium is a common contaminant released into water media from various industrial wastewaters including those from the electroplating, tanning of leather, dyeing of textile and metal finishing industries (Ahalya et al. 2005; Faisal and Hasnain 2004). Chromium exists in different oxidation states. Trivalent $\mathrm{Cr}(\mathrm{III})$ and the hexavalent $\mathrm{Cr}(\mathrm{VI})$ species are the most common and stable forms, which exhibit quite distinct chemical properties such as bioavailability, mobility and toxicities (Lim and Aris 2014). Cr(VI) regarded to be the most lethal of chromium is readily mobile, a strong oxidizing agent, and has the ability to be absorbed via the skin (Park and Jung 2001). It is also capable of being accumulated in water, soil, plants and living tissues, consequently becoming concentrated throughout the food chain (Bayuo et al. 2019a, b, c). 
Ion exchange, chemical precipitation, evaporation, solvent extraction, reverse osmosis, lime coagulation and electrolysis are conventional metal elimination techniques. However, these conventional procedures have some inherent restrictions including lower efficiency, sensitive operating conditions and secondary sludge production (Zarubica and Purenovic 2011) or other waste products, which require cautious disposal in further steps (Pandey et al. 2007). The most proficient and significant technology is the sorption of toxic metals from domestic to industrial wastewaters using activated carbon (Zarubica and Purenovic 2011). However, the expensive nature of the commercial activated carbon and its loss during regeneration limits its application (Sud et al. 2008).

Recently, alternative biosorbents for the decontamination of heavy metals from aqueous media have been considered with dependence on the adsorption capacities of waste materials, both organic and inorganic (Pandey et al. 2007). The materials that have been explored as biosorbents include agricultural and industrial waste materials such as groundnut shells (Bayuo et al. 2019a), Lagenaria vulgaris shell (Zarubica and Purenovic 2011) and peanut skins (Cimino et al. 2000). The major benefits of biosorption over conventional techniques include high efficiency, low cost, minimization of secondary sludge and the possibility to regenerate the biosorbent (Cimino et al. 2000). Agricultural waste materials with or without any modification have all been found to complex and sequester heavy metals (Bayuo et al. 2019a; Sud et al. 2008). This is attributable to their structural composition (cellulose, hemicellulose, lignin, proteins, lipids, simple sugars, hydrocarbons) and numerous functional groups such as carboxyl, carbonyl, hydroxyl, phenyl, ester, acetamido, amido, amino and sulphydryl found on the surfaces of biosorbents (Bayuo et al. 2019a).

In this work, the prepared unmodified adsorbent from Arachis hypogea shell was studied as a low-cost biosorbent for depolluting $\mathrm{Cr}(\mathrm{VI})$ from aqueous media. Statistical optimization of independent variables influencing the sorption process was examined with central composite design (CCD), a subset of response surface methodology (RSM) in Design-Expert software 12.0.0. Furthermore, three-parameter adsorption isotherm and kinetic models were explored to determine the models that best represent the equilibrium data.

\section{Materials and method}

\section{Materials}

The Arachis hypogea (groundnut) husks were collected from Kologo in Navrongo Municipal in the Upper East region of Ghana and use naturally as a biosorbent for the biosorption of $\mathrm{Cr}(\mathrm{VI})$ from water media. Arachis hypogea (groundnut) is a variety of leguminous crop which is a very essential legume found in Africa (Sellscope 1962). The types of Arachis hypogea are classified into a bunch and runner types. In the current study, the bunch type (Fig. 1a) was used and it has a well-built taproot with many lateral roots that outspread several inches into the soil. Most of the roots have nodules but bearing insufficient root hairs (Icrist 2005). The whole seed of Arachis hypogea is referred to as pod while the shell or husk (Fig. 1b) is the outer cover of Arachis hypogea. Groundnuts are an important plant in Ghana and are currently grown in temperate and tropical climates. Groundnut is an annual dicotyledon legume with a low growing plant and upright stem. In the whole of West Africa, Ghana has become the major groundnuts producer with the mainstream production coming from the North. Every year the northern parts of Ghana produce about $94 \%$ of groundnuts, and since 2004, groundnut production ranges between 400,000 and 450,000 MT (Owusu-adjei et al. 2017).

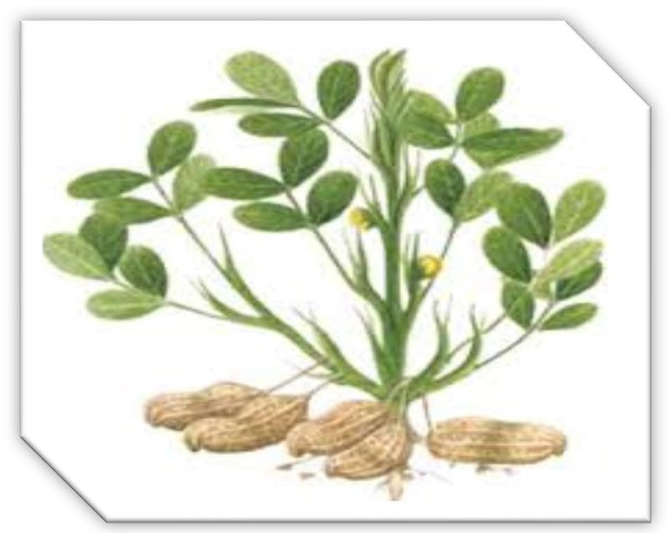

(a)

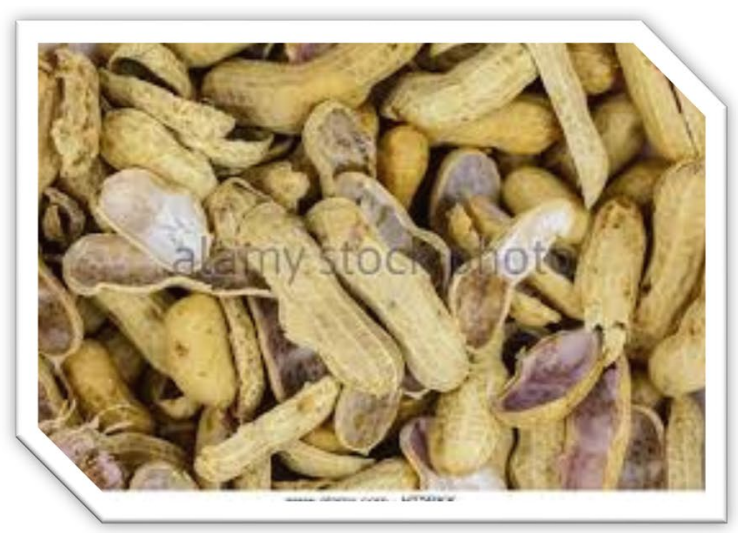

(b)

Fig. 1 Arachis hypogea plant (a) and Arachis hypogea husks (b)

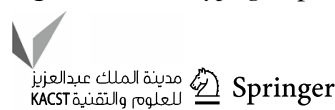


All the chemicals used in the study, including potassium dichromate $\left(\mathrm{K}_{2} \mathrm{Cr}_{2} \mathrm{O}_{7}\right)$, sodium hydroxide $(\mathrm{NaOH})$, hydrochloric acid $(\mathrm{HCl})$ and 1, 5-diphenylcarbazide, were of analytical grade obtained from Applied Chemistry and Biochemistry Laboratory of the University for Development Studies, Navrongo Campus, Ghana.

A $1000 \mathrm{mg} / \mathrm{L} \mathrm{Cr}(\mathrm{VI})$ stock solution was prepared by dissolving $2.83 \mathrm{~g}$ of $\mathrm{K}_{2} \mathrm{Cr}_{2} \mathrm{O}_{7}$ in $200 \mathrm{~mL}$ of deionized water in a $1000-\mathrm{mL}$ volumetric flask and toping up to the mark with deionized water. Various aqueous solutions of initial $\mathrm{Cr}(\mathrm{VI})$ concentrations were also prepared as required through the dilution of the stock solution to the desired volume using deionized water.

\section{Preparation of adsorbent}

The husks were locally collected and treated with distilled water to get rid of the attached dust and any other contaminations. The washed husks were dried in an oven at $105^{\circ} \mathrm{C}$ for $24 \mathrm{~h}$ to constant mass and ground to form a powder using a mechanical grinder. Standard mesh size was used to sieve the powder into a size fraction ranged between 250 and $300 \mu \mathrm{m}$ and utilized in all the adsorption experiments.

\section{Physicochemical parameters of Arachis hypogea husk}

The physicochemical parameters of the Arachis hypogea husk that were determined in the current study include moisture content, bulk density, surface area, $\mathrm{pH}$ and point of zero charge $\mathrm{pH}\left(\mathrm{pH}_{p z c}\right)$ of the biosorbent.

\section{Characterization of adsorbent}

The characterization of Arachis hypogea husk had been carried out in our previous study (Bayuo et al. 2019c) by way of Fourier transform infrared spectrometer to examine the surface functional groups of the adsorbent operating in the range 4000-400 $\mathrm{cm}^{-1}$. The characterization of the husk was done before and after the adsorption of $\mathrm{Cr}(\mathrm{VI})$ ions. Additionally, a Quantachrome analyzer was applied to determine the BET surface area and pore size distributions of the obtained unmodified adsorbent.

\section{Experimental design and statistical analysis}

Central composite design (CCD) was applied as an optimization tool of RSM, to explore the impact of the independent variables on the sorption process. To determine the optimum conditions, three process independent variables were considered: Contact time $(A), \mathrm{pH}$ of the aqueous solution $(B)$, initial $\mathrm{Cr}(\mathrm{VI})$ concentration $(C)$ and their influences on the uptake capacity of $\mathrm{Cr}(\mathrm{VI})$ were investigated.
The CCD involves $2^{n}$ factorial runs, $2 n$ axial runs and $n_{c}$ center runs. The center points determine the experimental error and how well the data can be reproduced. The axial points are taken in a way to ensure ratability, and the model prediction variance is constant at every point equidistant from the center of design (Mourabet et al. 2017).

The total experimental runs conducted are computed by Eq. (1) (Owolabi et al. 2018):

$N=2^{n}+2 n+n_{c}$

$N=2^{3}+2(3)+6=8+6+6=20$

where $n$ is number of independent variables (factors), $n_{c}$ is number of center points and $N$ is the overall total of experimental runs. This indicated that 20 experimental runs comprising 8 factorial runs, 6 axial runs and 6 center runs were prerequisites for the modeling and optimization process.

The experimental data obtained were studied by means of Design-Expert 12.0.0 software. The level of the considered independent variables and their experimental ranges for $\mathrm{Cr}(\mathrm{VI})$ adsorption capacity $(Y)$ are presented in Table 1 .

The purpose of the current study is to explore the optimum operating conditions for adsorption of $\mathrm{Cr}(\mathrm{VI})$ from aqueous media onto unmodified Arachis hypogea husk. However, the dependent variable (response) which is the adsorption capacity $(Y)$ was determined through the batch technique and was used to develop an empirical mathematical model. The model relates the response $(Y)$ to the three independent factors with a second-order polynomial expression as given in Eq. (2) (Bayuo et al. 2019b; Auta 2012)

$Y=b_{0}+\sum_{i=1}^{n} b_{i} X_{i}+\sum_{i=1}^{n} b_{i i} X_{i}^{2}+\sum_{i=1}^{n-1} \sum_{j=i+1}^{n} b_{i j} X_{i} X_{j}$

where $Y$ represents the response predicted, $b_{0}$ is the coefficient constant, $b_{i}$ signifies linear coefficient, $b_{i j}$ is the coefficient of interaction, $b_{i i}$ connotes quadratic coefficient and $X_{i}, X_{j}$ mean, coded values of factors.

\section{Batch adsorption studies}

The batch experiments of the unmodified Arachis hypogea husk were conducted in a set of each 250-mL Erlenmeyer

Table 1 Levels of the sorption process variables considered

\begin{tabular}{lllclr}
\hline Description & Variable & Unit & \multicolumn{2}{c}{ Level } & \\
\cline { 3 - 6 } & & & -1 & 0 & \multicolumn{1}{c}{1} \\
\hline Contact time & $\mathrm{A}$ & $\min$ & 60 & 90 & 120 \\
$\mathrm{pH}$ of solution & $\mathrm{B}$ & - & 6 & 7 & 8 \\
$\begin{array}{l}\text { Initial Cr(VI) } \\
\text { concentration }\end{array}$ & $\mathrm{C}$ & $\mathrm{mg} / \mathrm{L}$ & 15 & 32.5 & 50 \\
\hline
\end{tabular}


conical flasks containing $100 \mathrm{~mL}$ of the required concentration of an adjusted $\mathrm{pH}$ of $\mathrm{Cr}(\mathrm{VI})$ solution. The flasks were later capped and agitated at a constant stirring speed of $120 \mathrm{rpm}$. The experiments were carried out according to the experimental conditions obtained with experimental design (Table 5) for the required time intervals using magnetic stirrers until equilibrium operating conditions were achieved. Upon equilibrium attainment, the suspension of each sample was allowed to settle and filtered using Whatman 42 filter paper. The concentration of the $\mathrm{Cr}(\mathrm{VI})$ ions in the filtrate was determined spectrophotometrically (UV-Vis Spectrophotometer) by diphenyl-carbazide method (Bayuo et al. 2019c).

The $\mathrm{Cr}(\mathrm{VI})$ removal efficiency, $\mathrm{RE}(\%)$ and amount of $\mathrm{Cr}(\mathrm{VI})$ adsorbed at equilibrium, $q_{e}(Y), \mathrm{mg} / \mathrm{g}$, were determined as given in Eqs. (3, 4) (Bayuo et al. 2019a):

Removal efficiency $(\%)=\left(C_{O}-C_{e} / C_{o}\right) \times 100$

where $C_{o}$ is the initial $\mathrm{Cr}(\mathrm{VI})$ concentration $(\mathrm{mg} / \mathrm{L})$ and $C_{e}$ is the equilibrium $\mathrm{Cr}(\mathrm{VI})$ concentration $(\mathrm{mg} / \mathrm{L})$.

$q_{e}=\left(C_{o}-C_{e} / m\right) \times V$

where $q_{e}$ represents the equilibrium mass of the adsorbed substance per unit mass of adsorbent, $V$ is the volume of solution $(\mathrm{mL})$ and $\mathrm{m}$ is the mass of the adsorbent $(\mathrm{g})$.

\section{Equilibrium adsorption isotherm}

The potentiality of three-parameter adsorption isotherm models (Redlich-Peterson and Jossens) was tested with the purpose of choosing the most suitable model that would best describe and predict the biosorption of $\mathrm{Cr}(\mathrm{VI})$ onto the unmodified Arachis hypogea husk.

\section{Redlich-Peterson isotherm model}

This model is experiential in nature consisting of three parameters and combines Langmuir and Freundlich models (Toth 1971). The model is a mix-type that joins elements from Langmuir and Freundlich isotherm models, and the mechanism of adsorption is hybrid in nature; hence, ideal monolayer sorption does not take place (Foo and Hameed 2009). Through the Langmuir isotherm, the numerator of the equation is obtained and with the potential of reaching Henry's model through infinite dilution (Khan and Al-Haddad 1996). In addition, it shows linearized dependence on the concentration in the numerator and an exponential function in the denominator all denoting sorption equilibrium over vast solute concentration that is capable of being applied in homogeneous or else heterogeneous surfaces due to its versatility (Maximova and Koumanova 2008). The model can be expressed as in Eq. (5).

$q_{e}=\frac{A C_{e}}{1+B C_{e}^{\beta}}$

where $C_{e}$ denotes equilibrium concentration of the solute $(\mathrm{mg} / \mathrm{L}), q_{e}$ represents equilibrium uptake capacity $(\mathrm{mg} / \mathrm{g}), A$ $(\mathrm{L} / \mathrm{g}), B(\mathrm{~L} / \mathrm{mg})$ connote the constants of the Redlich-Peterson model and $\beta$ signifies an exponent positioned between 0 and 1 . At a very high solute concentration in the liquid phase, Eq. (6) becomes the Freundlich model.

$q_{e}=\frac{A}{B} C_{e}^{1-\beta}$

where $A / B=K_{\mathrm{F}}$ and $(1-\beta)=\frac{1}{n}$ of the Freundlich model, and when $\beta=1$, Eq. (6) becomes the Langmuir isotherm with $b=B$ [Langmuir constant $(\mathrm{L} / \mathrm{mg})$ that is interrelated to the adsorption energy]. $A=b q_{m}$, but $q_{m}$ refers to Langmuir's optimum uptake capacity of the solid ( $\mathrm{mg} / \mathrm{g})$.

When $\beta=0$, Eq. (6) becomes Henry's model having $\frac{A}{B}$ as Henry's constant $\left(K_{H E}\right)$. The linearized expression of the Redlich-Peterson model is expressed as in Eq. (7):

$\ln \left(\frac{C_{e}}{q_{e}}\right)=\beta \ln C_{e}-\ln A$

By plotting $\ln \left(\frac{C_{e}}{q_{e}}\right)$ against $\ln C_{e}$ (Fig. 2), $\beta$ and $A$ are obtained through the slope and intercept correspondingly.

\section{Jossens $\mathbf{n}$ isotherm model}

The Jossens model is an expression established due to the energy dissemination of solute-solid interactions at adsorbent adsorption sites (Dilekoglu 2016). The model posits the solid surface to be heterogeneous regarding the interactions between the solute. The Jossen model is presented in Eq. (8).

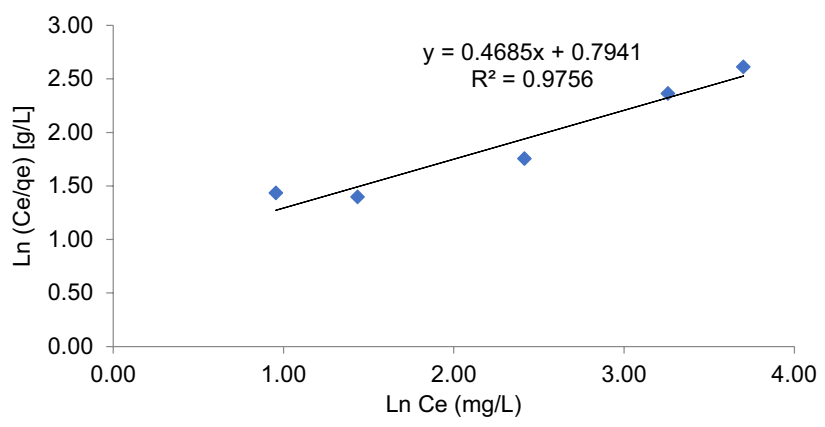

Fig. 2 Redlich-Peterson isotherm plot of $\mathrm{Cr}(\mathrm{VI})$ onto Arachis hypogea husk 


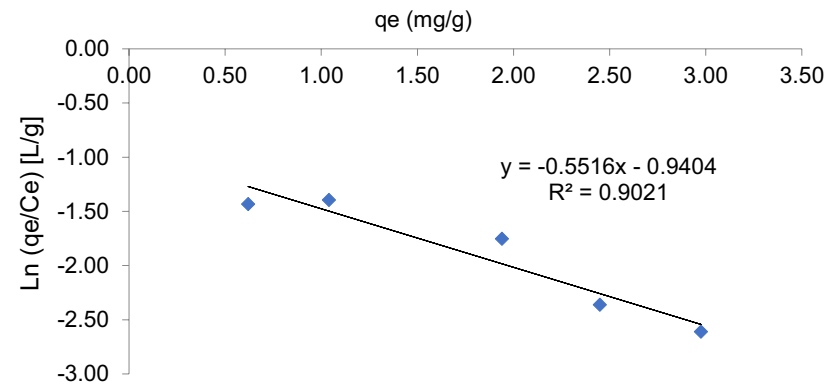

Fig. 3 Jossens isotherm plot of $\mathrm{Cr}(\mathrm{VI})$ onto Arachis hypogea husk

$C_{e}=\frac{q_{e}}{H} \exp \left(F q_{e}^{p}\right)$

where $C_{e}$ refers to equilibrium solute concentration $(\mathrm{mg} / \mathrm{L})$, $H$ and $F$ are Jossens isotherm constant and $p$ denotes a constant that is typical of the adsorbent regardless of temperature and the solid nature. Equation (8) becomes Henry's law at small capacities but upon rearranging Eq. (8) (Juang et al. 1996) yields Eq. (9):

$\ln \left(\frac{C_{e}}{q_{e}}\right)=-\ln (H)+F q_{e}^{p}$

The Jossens constants, $H$ and $F$, are obtained from the plot of $\ln \left(\frac{C_{e}}{q_{e}}\right)$ against $q_{e}$ (Fig. 3).

\section{Equilibrium Kinetic modeling}

The equilibrium data attained were applied to pseudo-firstorder and pseudo-second-order kinetic models to gain insight into the controlling mechanism of the biosorption of $\mathrm{Cr}$ (VI) on Arachis hypogea husk. The linearized forms of the pseudofirst-order (Lagergren 1898) and pseudo-second-order (Ho 2006) models are expressed in Eqs. (10) and (11), respectively, as follows:

$\log \left(q_{e}-q_{t}\right)=\log q_{e}-\frac{k_{p_{1}}}{2.303} t$

$\frac{t}{q_{t}}=\frac{1}{k_{p_{2}} q_{e^{2}}}+\frac{1}{q_{e}} t$

where $k_{p_{1}}\left(\mathrm{~min}^{-1}\right)$ and $k_{p_{2}}\left(\mathrm{gmg}^{-1} \mathrm{~min}^{-1}\right)$ are pseudo-firstorder rate and pseudo-second-order rate constants and $q_{e}$

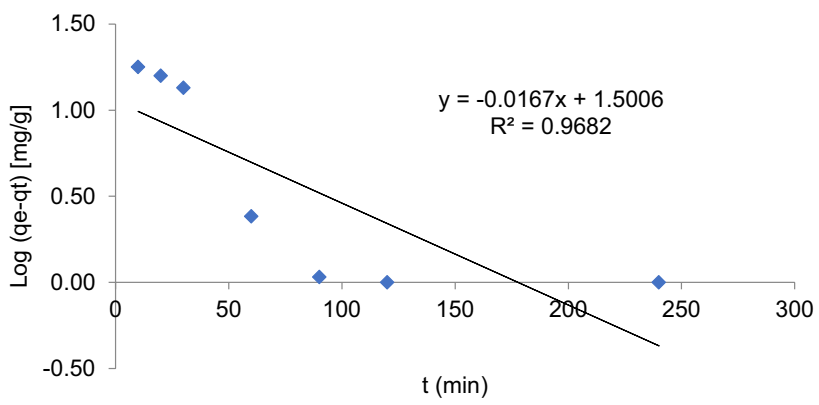

Fig. 4 Pseudo-first-order plot of $\mathrm{Cr}(\mathrm{VI})$ onto Arachis hypogea husk

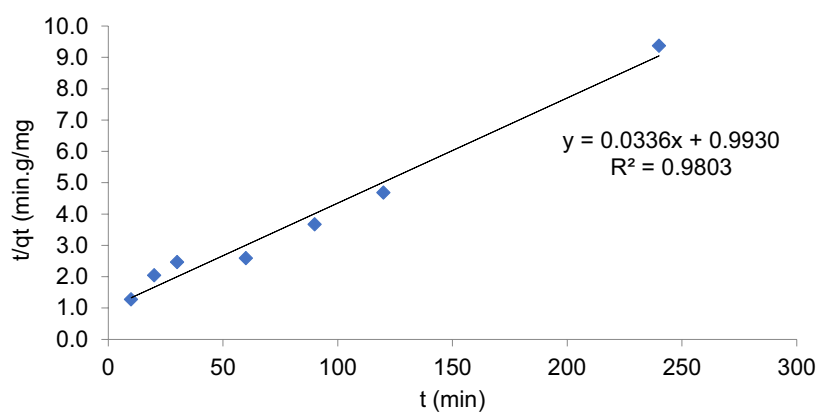

Fig. 5 Pseudo-second-order plot of $\mathrm{Cr}(\mathrm{VI})$ onto Arachis hypogea husk

Table 2 Physicochemical parameters of the adsorbent (Arachis hypogea husk)

\begin{tabular}{lr}
\hline Parameter & $\begin{array}{l}\text { Arachis } \\
\text { hypogea } \\
\text { husk }\end{array}$ \\
\hline Moisture content $(\%)$ & 8.410 \\
Bulk density $\left(\mathrm{g} / \mathrm{cm}^{3}\right)$ & 0.460 \\
$\mathrm{pH}$ & 7.280 \\
Surface area $\left(\mathrm{m}^{2} / \mathrm{g}\right)$ & 432.600 \\
Point of zero charge $\mathrm{pH}$ & 5.500
\end{tabular}

and $q_{t}(\mathrm{mg} / \mathrm{g})$ are the sorption capacities at equilibrium and time $t$ ( $\mathrm{min})$, respectively.

By plotting $\log \left(q_{e}-q_{t}\right)$ versus $t$ (Fig. 4) and $\frac{t}{q_{t}}$ versus $t$ (Fig. 5), the constants $k_{p_{1}}, k_{p_{2}}$ and $q_{e}$ can be obtained.

\section{Results and discussions}

\section{Physicochemical parameters of groundnut husk}

The results of the physicochemical properties of the adsorbent are reported in Table 2. 
The quality of a produced biosorbent can be enriched by reducing the adsorbent moisture content. The Arachis hypogea husk low moisture content ( 8.41 percent) indicated better yield and biosorbent quality. The Arachis hypogea husk moisture level was lower than the percentage moisture content obtained from Osakwe et al. (2014) and Okuofu and Osakwe (2012) using raw and carbonized baobab fruit shells and Theobroma cacao pods, and Borrassus Aethiopium and Cocos Nucifera, respectively. This implied that the Arachis hypogea husk used for the decontamination of $\mathrm{Cr}(\mathrm{VI})$ was of quality and there was no interference of moisture with the process, hence the higher the $\mathrm{Cr}(\mathrm{VI})$ uptake onto the Arachis hypogea husk.

As suggested by Amuda et al. (2007), the bulk density $\left(0.46 \mathrm{~g} / \mathrm{cm}^{3}\right)$ was found to be greater than $0.25 \mathrm{~g} / \mathrm{cm}^{3}$, and this showed better biosorbent filterability.

In most adsorption tests, the point of zero charge $\mathrm{pH}$ $\left(\mathrm{pH}_{p z c}\right)$ should be related to the $\mathrm{pH}$ of the adsorption system as $\mathrm{pH}_{p z c}$ established the limitations of the adsorbent $\mathrm{pH}$ (Abas et al. 2014). In the present work, the $\mathrm{pH}_{z p c}$ (5.5) of the biosorbent was found to be lower than the $\mathrm{pH}(6.0)$ of the adsorption media, which produced a more negative charge on the Arachis hypogea husk surface. An upsurge in the negative charge density on the Arachis hypogea husk surface improved the decontamination of $\mathrm{Cr}(\mathrm{VI})$ (Ofudje et al. 2015). Similar findings had been recounted in the literature (Abdullah et al. 2014 and Yu et al. 2011).

Using the Saers' method (Dada et al. 2012; Shawabkeh and Tutunji 2003 and Saer 1956), the specific surface area of the adsorbent was obtained as $432.60 \mathrm{~m}^{2} / \mathrm{g}$ signifying high surface area and porous nature of the Arachis hypogea husk. Abudaia et al. (2013) in a study discovered that the adsorption capacity of the adsorbent exhibited dependence largely on the surface area available for the adsorbate interaction. Generally, the greater the surface area, the higher the number of metal ions adsorbed on the surface of the adsorbent. This could be due to an increase in the number of binding

Table 3 Background concentration of chromium (VI) in Arachis hypogea husk

\begin{tabular}{lll}
\hline Metal ion & Concentration $(\mathrm{mg} / \mathrm{L})$ & Comment \\
\hline Chromium (VI) & $<0.0001$ & BDL \\
\hline
\end{tabular}

sites on the biosorbent surface for the adsorptive removal of the metal ions (Oboh et al. 2009).

Furthermore, the raw sample (Arachis hypogea husk) was digested (by wet digestion) to determine the background concentration of $\mathrm{Cr}(\mathrm{VI})$ (Table 3 ). The background concentration of the $\mathrm{Cr}(\mathrm{VI})$ in the Arachis hypogea husk was found to be below the detection limit (BDL) of the UV-Vis spectrophotometer (Cary 60) which implied that the Arachis hypogea husks were initially free from $\mathrm{Cr}(\mathrm{VI})$ ions contamination.

\section{Characterization of the adsorbent}

The FTIR analysis conducted in our previous study (Bayuo et al. 2019c) showed that the Arachis hypogea husk has surface functional groups (carboxyl, carbonyl, hydroxyl, phenyl, amino, and ester) that were accountable for the biosorption of $\mathrm{Cr}(\mathrm{VI})$ from the aqueous media.

Furthermore, the BET surface area of the unmodified Arachis hypogea husk was found to decline after loading with $\mathrm{Cr}(\mathrm{VI})$ ions. Moreover, the total pore volume of the biosorbent decreases significantly after the removal of $\mathrm{Cr}(\mathrm{VI})$ onto the surface of the Arachis hypogea husk (Bayuo et al. 2019c).

\section{Central composite design (CCD) model and data analysis}

The 3-factor CCD design matrix produced by the software and the experimental data attained in the batch adsorption of $\mathrm{Cr}(\mathrm{VI})$ by Arachis hypogea husk are summarized in Table 5.

A quadratic model that relates the adsorption capacity (response) and the independent parameters were chosen by the CCD (Table 4) and described in terms of the coded parameters by the second-order polynomial equation as given in Eq. (12):

$$
\begin{aligned}
Y= & 1.33-0.0612 A+0.4162 B+0.6251 C+0.0015 A B-0.0052 A C \\
& +0.2347 B C-0.1322 A^{2}-0.1676 B^{2}-0.0049 C^{2}
\end{aligned}
$$

The predicted $\mathrm{Cr}(\mathrm{VI})$ adsorption capacity $(\mathrm{mg} / \mathrm{g})$ obtained by Eq. (12) is shown in Table 5. The residuals between the predicted and experimental (actual) values were found to be low implying that both the predicted and experimental
Table 4 Model summary statistics for adsorption capacity (response $\mathrm{Y}$ ) of $\mathrm{Cr}(\mathrm{VI})$ ion

\begin{tabular}{lllllll}
\hline Source & $\mathrm{SD}$ & $\mathrm{R}^{2}$ & Adjusted $\mathrm{R}^{2}$ & Predicted $\mathrm{R}^{2}$ & Press & Comment \\
\hline Linear & 0.2781 & 0.8699 & 0.8438 & 0.7498 & 2.23 & \\
2FI & 0.2448 & 0.9193 & 0.8790 & 0.7603 & 2.14 & \\
Quadratic & 0.1122 & 0.9873 & 0.9746 & 0.8759 & 1.11 & Suggested \\
Cubic & 0.0493 & 0.9986 & 0.9951 & 0.1272 & 7.78 & Aliased \\
\hline
\end{tabular}


Table 5 Design matrix for $\mathrm{Cr}(\mathrm{VI})$ adsorption factors and corresponding responses from the experiment

\begin{tabular}{|c|c|c|c|c|c|c|c|c|c|}
\hline \multirow[t]{2}{*}{ Run } & \multirow[t]{2}{*}{ Space type } & \multicolumn{3}{|c|}{ Coded factors } & \multicolumn{3}{|c|}{ Uncoded factors } & \multicolumn{2}{|c|}{ Adsorption capacity (Y) } \\
\hline & & $\mathrm{A}(\mathrm{min})$ & B & $\mathrm{C}(\mathrm{mg} / \mathrm{L})$ & $\mathrm{A}(\mathrm{min})$ & B & $\mathrm{C}(\mathrm{mg} / \mathrm{L})$ & $\begin{array}{l}\text { Predicted } \\
\text { values } \\
(\mathrm{mg} / \mathrm{g})\end{array}$ & $\begin{array}{l}\text { Experimental } \\
\text { values }(\mathrm{mg} / \mathrm{g})\end{array}$ \\
\hline 1 & Factorial & +1 & +1 & +1 & 120 & 8 & 50.0 & 2.364 & 2.355 \\
\hline 2 & Center & 0 & 0 & 0 & 90 & 7 & 32.5 & 1.562 & 1.405 \\
\hline 3 & Factorial & -1 & +1 & -1 & 60 & 8 & 15.0 & 0.700 & 0.690 \\
\hline 4 & Factorial & +1 & -1 & -1 & 120 & 6 & 15.0 & 0.298 & 0.360 \\
\hline 5 & Factorial & -1 & -1 & -1 & 60 & 6 & 15.0 & 0.411 & 0.320 \\
\hline 6 & Center & 0 & 0 & 0 & 90 & 7 & 32.5 & 1.423 & 1.385 \\
\hline 7 & Center & 0 & 0 & 0 & 90 & 7 & 32.5 & 1.126 & 1.370 \\
\hline 8 & Factorial & +1 & +1 & -1 & 120 & 8 & 15.0 & 0.764 & 0.682 \\
\hline 9 & Center & 0 & 0 & 0 & 90 & 7 & 32.5 & 1.432 & 1.345 \\
\hline 10 & Factorial & -1 & +1 & +1 & 60 & 8 & 50.0 & 2.623 & 2.330 \\
\hline 11 & Factorial & -1 & -1 & +1 & 60 & 6 & 50.0 & 1.238 & 1.075 \\
\hline 12 & Factorial & +1 & -1 & +1 & 120 & 6 & 50.0 & 1.053 & 1.040 \\
\hline 13 & Axial & 1.682 & 0 & 0 & 140.454 & 7 & 32.5 & 0.762 & 0.610 \\
\hline 14 & Axial & 0 & -1.682 & 0 & 90 & 5.318 & 32.5 & 0.086 & 0.045 \\
\hline 15 & Axial & 0 & 1.682 & 0 & 90 & 8.682 & 32.5 & 1.298 & 1.485 \\
\hline 16 & Axial & 0 & 0 & -1.682 & 90 & 7 & 3.069 & 0.119 & 0.098 \\
\hline 17 & Center & 0 & 0 & 0 & 90 & 7 & 32.5 & 1.268 & 1.320 \\
\hline 18 & Axial & -1.682 & 0 & 0 & 39.546 & 7 & 32.5 & 1.321 & 1.120 \\
\hline 19 & Center & 0 & 0 & 0 & 90 & 7 & 32.5 & 1.162 & 1.290 \\
\hline 20 & Axial & 0 & 0 & 1.682 & 90 & 7 & 61.931 & 2.322 & 2.352 \\
\hline
\end{tabular}

responses had strong agreements (Mohammad et al. 2014). The correlation coefficient $\left(R^{2}\right)$ used to determine the relationship between the experimental (actual) and predicted responses was 0.9873 as established by the model. This suggests that the process parameters analyzed explain $98.73 \%$ of the adsorption capacity variability and that the model could not explain only $1.27 \%$ of the variation of the response (Garba et al. 2016).

Furthermore, the analysis of variance (ANOVA) was used to determine the adequacy of the model. Table 6 presents the results of the quadratic response surface model fitting in the form of ANOVA. According to Yusuff (2018), ANOVA divides the complete variation of the results into
Table 6 ANOVA for quadratic model for adsorption capacity (response $\mathrm{Y}$ ) of $\mathrm{Cr}(\mathrm{VI})$

\begin{tabular}{llrlrrl}
\hline Source & Sum of squares & df & Mean square & F-value & p value & Comment \\
\hline Block & 0.1174 & 1 & 0.1174 & & & \\
Model & 8.80 & 9 & 0.9778 & 77.67 & $<0.0001$ & Significant \\
A-contact time & 0.0511 & 1 & 0.0511 & 4.06 & 0.0747 & \\
B-pH & 2.37 & 1 & 2.37 & 187.91 & $<0.0001$ & Significant \\
C-initial concentration & 5.34 & 1 & 5.34 & 423.95 & $<0.0001$ & Significant \\
AB & 0.0000 & 1 & 0.0000 & 0.0014 & 0.9707 & \\
AC & 0.0002 & 1 & 0.0002 & 0.0175 & 0.8976 & \\
BC & 0.4409 & 1 & 0.4409 & 35.02 & 0.0002 & Significant \\
$\mathrm{A}^{2}$ & 0.2518 & 1 & 0.2518 & 20.00 & 0.0015 & Significant \\
$\mathrm{B}^{2}$ & 0.4044 & 1 & 0.4044 & 32.12 & 0.0003 & Significant \\
$\mathrm{C}^{2}$ & 0.0004 & 1 & 0.0004 & 0.0280 & 0.8708 & \\
Residual & 0.1133 & 9 & 0.0126 & & & \\
Lack of fit & 0.1109 & 5 & 0.0222 & 3.22 & 0.0819 & Not significant \\
Pure error & 0.0024 & 4 & 0.0069 & & & \\
Cor total & 9.03 & 19 & & & & \\
\hline
\end{tabular}


two variations: one associated with the model and the other with experimental errors so as to determine whether the variation from the model is significant or not. This is calculated by evaluating the $F$-value expressed as the square-to-residual error ratio of the mean model. If the calculated $F$-value is found to be greater than that of the tabulated F-value, then the model is a strong experimental data predictor (Ani et al. 2015). The F-value obtained in the present study was 77.67 , which suggested the fitness of the response surface model. More so, the significance of each of the model terms was evaluated using the probability of error value (Prob $>F)$. In Table 6, the values of Prob $>F$ less than 0.0500 showed that the terms are significant (Garba et al. 2016). It is found that $B, C, A^{2}, B^{2}$ and $C^{2}$ were the significant model terms, whereas $A, A B, A C$ and $B C$ were the insignificant terms for adsorption capacity of $\mathrm{Cr}(\mathrm{VI})$. Hence, based on the $F$-value (Table 6), the three process variables studied had a significant effect on the $\mathrm{Cr}(\mathrm{VI})$ adsorption capacity. The initial $\mathrm{Cr}(\mathrm{VI})$ concentration $(C)$ had the highest $F$-value of 423.95 implying that it had the most significant influence on the adsorption of $\mathrm{Cr}(\mathrm{VI})$ in comparison with contact time $(A)$ and $\mathrm{pH}$ of the solution (B) (Gottipati et al. 2012). However, only quadratic effects of contact time $(A)$ and $\mathrm{pH}$ of solution $(B)$ on adsorption capacity of $\mathrm{Cr}(\mathrm{VI})$ were significant. In Table 6, the lack of fit $F$-value of 0.1109 showed the lack of fit is not significant relative to the pure error. Nonsignificant lack of fit, however, is good because the model is geared toward perfect fitness (Bayuo et al. 2019b).

The second-order polynomial Eq. (12) in terms of coded parameters after removing the nonsignificant model terms is given in Eq. (13).
$Y=1.33+0.4162 B+0.6251 C+0.2347 B C-0.1322 A^{2}-0.1676 B^{2}$

Figure 6 represents the 3D surface plot of $\mathrm{Cr}(\mathrm{VI})$ adsorption capacity at a constant initial $\mathrm{Cr}(\mathrm{VI})$ concentration $(C)$ as a function of contact time $(A)$ and $\mathrm{pH}$ of the solution $(B)$. The Arachis hypogea husk adsorption capacity of $\mathrm{Cr}(\mathrm{VI})$ was found to be rapid at the initial stage as shown in Fig. 6. The improvement in the adsorption capacity at the start of the adsorption cycle could be attributable to the availability of large surface area for bulk adsorption of the $\mathrm{Cr}(\mathrm{VI})$ ions onto the husk (Bayuo et al. 2019a). The maximum adsorption of $\mathrm{Cr}(\mathrm{VI})$ was nearly accomplished at a constant initial $\mathrm{Cr}(\mathrm{VI})$ concentration of $50 \mathrm{mg} / \mathrm{L}$ at about $90 \mathrm{~min}$ of contact time. However, a further increase in contact time led to a rise in $\mathrm{Cr}(\mathrm{VI})$ uptake capacity until optimum removal of $\mathrm{Cr}(\mathrm{VI})$ by Arachis hypogea husk was accomplished at $120 \mathrm{~min}$ of equilibrium time.

Figure 7 is a 3D surface plot indicating the combined effects of contact time $(A)$ and initial $\mathrm{Cr}(\mathrm{VI})$ concentration $(C)$ on the adsorption capacity $(Y)$ of $\mathrm{Cr}(\mathrm{VI})$ at constant $\mathrm{pH}$ of the solution $(B)$. At the constant $\mathrm{pH}$ of the solution, it was observed that the variation of contact time and initial $\mathrm{Cr}(\mathrm{VI})$ concentration had a reasonably joint impact on the adsorption capacity $(Y)$. At higher values of the two parameters, the collective effect was greater. In addition, it was discovered that by increasing initial $\mathrm{Cr}(\mathrm{VI})$ concentration, the uptake capacity generally increased. This is because higher concentration levels provide an improved concentration gradient, an essential driving force that helps to resolve the mass transfer resistance of the $\mathrm{Cr}(\mathrm{VI})$ ions between the liquid and solid phases (Futalan et al. 2012).

Factor Coding: Actual

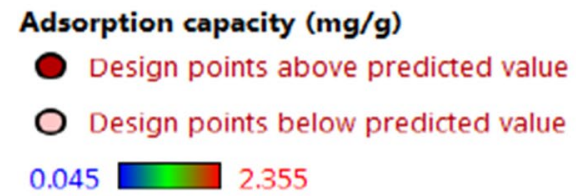

Adsorption capacity $(\mathrm{mg} / \mathrm{g})=2.355$

Std $\# 8$ Run $\# 1$

$\mathrm{X} 1=\mathrm{A}$ : Contact time $=120$

$\mathrm{X} 2=\mathrm{B}: \mathrm{pH}=8$

Actual Factor

$C:$ Initial concentration $=50$

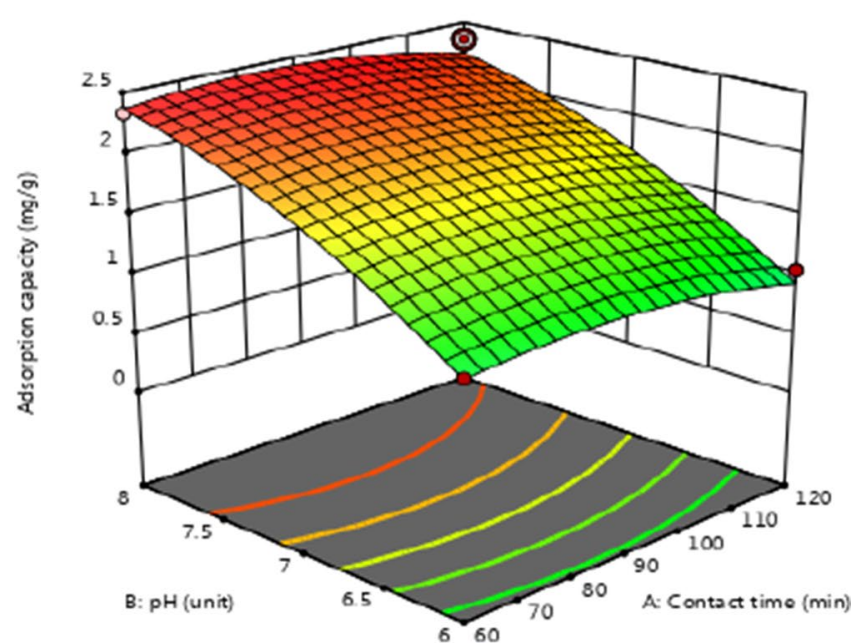

Fig. 6 Combined effect of factors A-B on adsorption capacity (response Y) of $\mathrm{Cr}(\mathrm{VI})$ onto Arachis hypogea husk

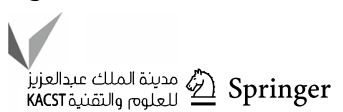


Factor Coding: Actual

\section{Adsorption capacity ( $\mathbf{m g} / \mathbf{g}$ ) \\ - Design points above predicted value \\ Design points below predicted value}

0.045

2.355

Adsorption capacity $(\mathrm{mg} / \mathrm{g})=2.355$

Std \# 8 Run \# 1

$\mathrm{X} 1=\mathrm{A}:$ Contact time $=120$

$\mathrm{X} 2=\mathrm{C}:$ Initial concentration $=50$

\section{Actual Factor}

B: $\mathrm{pH}=8$

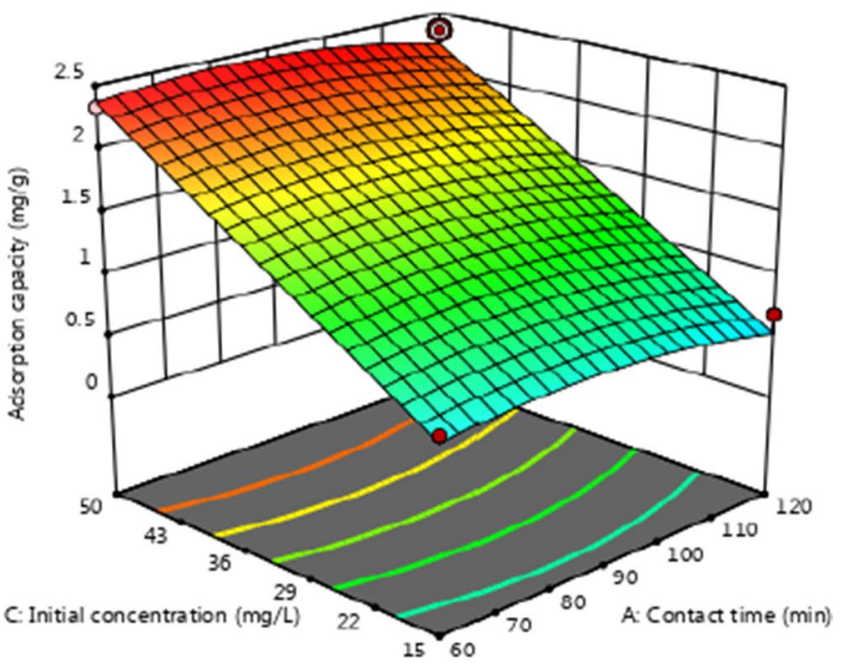

Fig. 7 Combined effect of factors A-C on adsorption capacity (response $\mathrm{Y}$ ) of $\mathrm{Cr}(\mathrm{VI})$ onto Arachis hypogea husk

Factor Coding: Actual

Adsorption capacity $(\mathbf{m g} / \mathbf{g})$

Design points above predicted value

0.045

2.355

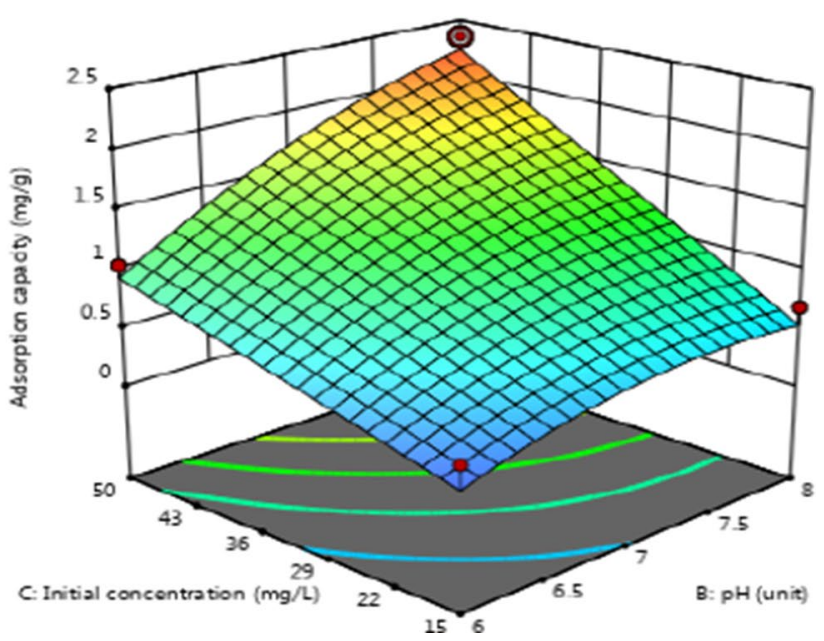

Fig. 8 Combined effect of factors B-C on adsorption capacity (response $\mathrm{Y}$ ) of $\mathrm{Cr}(\mathrm{VI})$ onto Arachis hypogea husk

Figure 8 depicts the 3D surface plot representing the mutual effects of the solution $\mathrm{pH}(B)$ and initial $\mathrm{Cr}(\mathrm{VI})$ concentration $(C)$ at constant contact time $(A)$. Figure 8 revealed that $\mathrm{Cr}(\mathrm{VI})$ adsorption capacity increased with decreasing initial $\mathrm{pH}$ of the solution. This is attributable to the point of zero charge $\mathrm{pH}\left(\mathrm{pH}_{\mathrm{zpc}}\right)$ of the Arachis hypogea husk as a biosorbent (Bayuo et al. 2019c). It has been established that when the $\mathrm{pH}$ of the solution is less than that of the $\mathrm{pH}_{\mathrm{zpc}}$ of the biosorbent, a positive charge is usually created on its surface, thereby decreasing the uptake capacity of the cations (Yusuff 2018; Mourabet et al. 2017). In the present study, the $\mathrm{pH}$ of the aqueous media $(\mathrm{pH}=8.0)$ was greater than that of the point of zero charge $\mathrm{pH}\left(\mathrm{pH}_{\mathrm{zpc}}\right)$ of the Arachis hypogea husk ( $\mathrm{pH}=5.5$ ). Thus, $\mathrm{pH}>\mathrm{pH}_{\mathrm{zpc}}$ signifying that the surface of the Arachis hypogea husk turns out to be negatively charged and upsurges the decontamination $\mathrm{Cr}(\mathrm{VI})$ from the aqueous media (Bayuo et al. 2019c).

\section{Optimization of the adsorption process}

In the optimization analysis, a goal criterion was set as maximum values for the three independent factors and one dependent factor (response) for the adsorption of $\mathrm{Cr}(\mathrm{VI})$ by the Arachis hypogea husk. For the independent factors, 


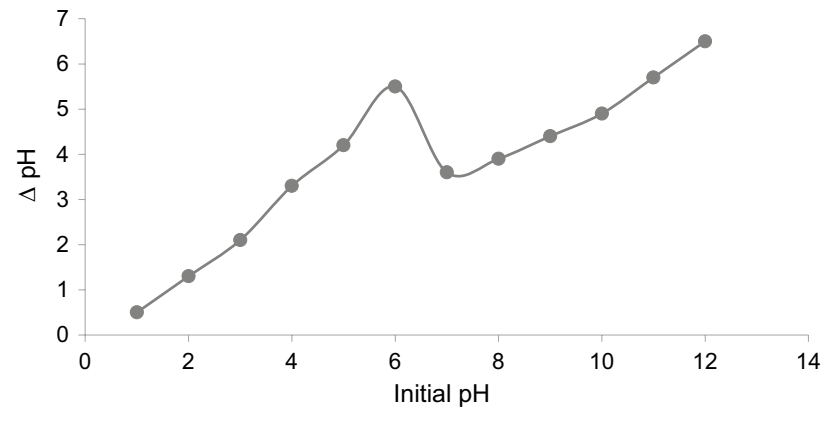

Fig. 9 Point of zero charge $\mathrm{pH}$ of the adsorbent (Arachis hypogea husk)

the goal was to obtain optimum values for which optimum response would be achieved (Fig. 9).

Therefore, by applying the desirability function, the optimum response (adsorption capacity) was found to be $2.234 \mathrm{mg} / \mathrm{g}$ at a contact time of $120 \mathrm{~min}, \mathrm{pH}$ of 8.0 and initial $\mathrm{Cr}(\mathrm{VI})$ concentration of $50 \mathrm{mg} / \mathrm{L}$ with good desirability of 0.969 . At this optimum process condition, the residual between the predicted response $(2.234 \mathrm{mg} / \mathrm{g})$ and the experimental response $(2.355 \mathrm{mg} / \mathrm{g})$ was found to be only $0.11 \mathrm{mg} / \mathrm{g}$ indicating that the regression quadratic model was valid and accurate in predicting the response $(Y)$ (Bayuo et al. 2019b).

The high optimum adsorption capacity of $2.355 \mathrm{mg} / \mathrm{g}$ obtained at the maximum values of the factors suggests that the unmodified Arachis hypogea husk as a non-conventional adsorbent has the potential of depolluting contaminants especially heavy metals from aqueous media (Bayuo et al. 2019a).

\section{Adsorption equilibrium isotherm}

From the three-parameter isotherm models investigated, it was found that Redlich-Peterson isotherm (Fig. 2) fitted well to the experimental data with good correlation coefficient of 0.9756 as compared to Jossens' model.

Table 7 Calculated values of the various isotherm models constants and their correlation coefficients $\left(\mathrm{R}^{2}\right)$ for the adsorption of $\mathrm{Cr}(\mathrm{VI})$ onto Arachis hypogea husk

\begin{tabular}{lll}
\hline Model & Parameter & Value \\
\hline Redlich-Peterson & $A$ & 0.452 \\
& $\beta$ & 0.469 \\
& $R^{2}$ & 0.9756 \\
Jossens & $H$ & 2.561 \\
& $F$ & 0.552 \\
& $R^{2}$ & 0.9021 \\
\hline
\end{tabular}

The fitness of the experimental data to Redlich-Peterson isotherm suggested that the adsorption mechanism is a mixed type and did not necessarily follow the ideal monolayer adsorption (Toth 1971). This is because the Redlich-Peterson isotherm is a blend of the Langmuir and Freundlich models, and therefore, the adsorption of the metal ions could occur on homogeneous and heterogeneous surfaces of the adsorbent (Foo and Hameed 2009). The relative high values of $\beta$ and $A$ for both metal ions further confirmed the fitness of the experimental data of $\mathrm{Cr}(\mathrm{VI})$ to the Redlich-Peterson isotherm model (Table 7).

\section{Equilibrium adsorption kinetics}

The adsorption kinetics was carried out by studying the adsorptive removal of the $\mathrm{Cr}(\mathrm{VI})$ at different time intervals. Two different models were applied to the experimental data to determine the mechanisms of adsorption and sole ratelimiting steps. The linear plots of the kinetic models are given in Figs. 4 and 5 while the calculated values of their constants and correlation coefficients $\left(R^{2}\right)$ are presented in Table 8.

The results in Table 8 showed that the experimental data of both metal ions fitted the two kinetic models analyzed. The plots of pseudo-first- and pseudo-second-order models showed that the uptake of $\mathrm{Cr}(\mathrm{VI})$ onto Arachis hypogea husk followed both pseudo-first- and pseudo-second-order reaction with good correlation coefficients as shown in Figs. 4 and 5, respectively. However, it was found that the pseudosecond-order model of $\mathrm{Cr}(\mathrm{VI})$ showed outstanding linearity with good correlation coefficients $\left(R^{2}=0.9803\right)$ in contrast to the pseudo-first-order model $\left(R^{2}=0.9682\right)$ tested, hence the best fit.

The fitness of the experimental data to pseudo-first- and pseudo-second-order models could be implied that the removal of $\mathrm{Cr}(\mathrm{VI})$ by the Arachis hypogea husk was due to physisorption and chemisorption processes (Bayuo et al. 2019a), respectively. The higher uptake capacities $\left(q_{e}\right)$ and rate constants of the pseudo-first-order- $\left(\mathrm{Kp}_{1}\right)$ and pseudosecond-order $\left(\mathrm{Kp}_{2}\right)$ models (Table 8$)$ of both metal ions

Table 8 Calculated values of the various kinetic models' constants and their correlation coefficients $\left(\mathrm{R}^{2}\right)$ for the adsorption of $\mathrm{Cr}(\mathrm{VI})$ onto Arachis hypogea husk

\begin{tabular}{llc}
\hline Kinetic model & Parameter & Parameter value \\
\hline Pseudo-first-order & $\mathrm{Kp}_{1}(\mathrm{~L} / \mathrm{min})$ & 0.038 \\
& $q_{e}(\mathrm{mg} / \mathrm{g})$ & 31.666 \\
& $R^{2}$ & 0.9682 \\
Pseudo-second-order & $\mathrm{Kp}_{2}(\mathrm{~L} / \mathrm{min})$ & 0.001 \\
& $q_{e}(\mathrm{mg} / \mathrm{g})$ & 29.762 \\
& $R^{2}$ & 0.9803
\end{tabular}


confirmed that the experimental data agreed with these models.

\section{Conclusion}

The optimization of $\mathrm{Cr}(\mathrm{VI})$ adsorption from aqueous solution by the unmodified Arachis hypogea husk showed that contact time, $\mathrm{pH}$ of the solution and initial $\mathrm{Cr}(\mathrm{VI})$ concentration had a significant effect on adsorption capacity of $\mathrm{Cr}(\mathrm{VI})$. As discovered by RSM, the interaction among the process variables studied improved the adsorption of $\mathrm{Cr}(\mathrm{VI})$. At the following optimum operation conditions: $120 \mathrm{~min}$ contact time, $8.0 \mathrm{pH}$ of solution and $50 \mathrm{mg} / \mathrm{L}$ initial $\mathrm{Cr}(\mathrm{VI})$ concentration, the maximum $\mathrm{Cr}(\mathrm{VI})$ uptake of $2.355 \mathrm{mg} / \mathrm{g}$ was achieved. Redlich-Peterson isotherm provided the best fit to the experimental data, indicating that the adsorption mechanism of $\mathrm{Cr}(\mathrm{VI})$ by Arachis hypogea husk adsorbent is a mixed type and did not necessarily follow ideal monolayer adsorption but could occur on both homogeneous and heterogeneous surfaces of the adsorbent. The experimental data were well predicted by the pseudo-second-order kinetic model. It can, therefore, be concluded that the adsorbent from Arachis hypogea husk is highly efficient for the elimination of $\mathrm{Cr}(\mathrm{VI})$ from any water media.

Acknowledgments The authors appreciate the effort of the management of the University for Development Studies for equipping the Applied Chemistry and Biochemistry Laboratory for core teaching and research work where this research work was conducted.

\section{Compliance with ethical standards}

Conflict of interest The authors declare that they have no conflict of interest.

Open Access This article is licensed under a Creative Commons Attribution 4.0 International License, which permits use, sharing, adaptation, distribution and reproduction in any medium or format, as long as you give appropriate credit to the original author(s) and the source, provide a link to the Creative Commons licence, and indicate if changes were made. The images or other third party material in this article are included in the article's Creative Commons licence, unless indicated otherwise in a credit line to the material. If material is not included in the article's Creative Commons licence and your intended use is not permitted by statutory regulation or exceeds the permitted use, you will need to obtain permission directly from the copyright holder. To view a copy of this licence, visit http://creativecommons.org/licenses/by/4.0/.

\section{References}

Abas SNA, Ismail MHS, Kamal ML, Izhar S (2014) Adsorption process of heavy metals by low-cost adsorbent: a review. Res J Chem Environ 18(4):91-102. https://doi.org/10.5829/idosi .wasj.2013.28.11.1874
Abdullah NN, Sulaiman F, Aani FN, Zailani R, Abdul Hamid SB, Chowdhury ZZ, May O (2014) New trends in removing heavy metals fromindustrial wastewater. Procedia Environ Sci 3(1):1-9. https://doi.org/10.1016/j.arabjc.2010.07.019

Abudaia JA, Sulyman MO, Elazaby KY, Ben-Ali SM (2013) Adsorption of $\mathrm{Pb}$ (II) and $\mathrm{Cu}$ (II) from aqueous solution onto activated carbon prepared from dates stones. Int J Environ Sci Dev 4(2):191195. https://doi.org/10.7763/IJESD.2013.V4.333

Amuda OS, Giwa A, Bello IA (2007) Removal of heavy metal from industrial wastewater using modified activated coconut shell carbon. Biochem Eng J 36(2):174-181

Ani I, Okafor J, Olutoye M, Akpan U (2015) Optimization of base oil regeneration from spent engine oil via solvent extraction. Adv Res. https://doi.org/10.9734/air/2015/16795

Auta M (2012) Optimization of tea waste activated carbon preparation parameters for removal of cibacron yellow dye from textile waste waters. Int J Adv Eng Res 1(4):50-56

Ahalya N, Kanamadi RD, Ramachandra TV (2005) Biosorption of chromium (VI) from aqueous solutions by the husk of Bengal gram (Cicer arientinum). Electron J Biotechnol 8(3):258-264. https://doi.org/10.2225/vol8-issue3-fulltext-10

Barakat MA (2011) New trends in removing heavy metals from industrial wastewater. Arab J Chem 4(4):361-377. https://doi. org/10.1016/j.arabjc.2010.07.019

Bayuo J, Pelig-Ba KB, Abukari MA (2018) Isotherm modeling of lead(II) adsorption from aqueous solution using groundnut shell as a low-cost adsorbent. IOSR J Appl Chem (IOSR-JAC) 11(11):18 23. https://doi.org/10.9790/5736-1111011823

Bayuo J, Abukari MA, Pelig-Ba KB (2019a) Equilibrium isotherm studies for the sorption of hexavalent chromium(VI) onto groundnut shell. IOSR J Appl Chem (IOSR-JAC), 11(12):40-46. https:// doi.org/10.9790/5736-1112014046

Bayuo J, Pelig-Ba KB, Abukari MA (2019b) Optimization of adsorption parameters for effective removal of lead(II) from. Phys Chem Indian J 14(1): 1-25

Bayuo J, Pelig-Ba KB, Abukari MA (2019c) Adsorptive removal of chromium(VI) from aqueous solution unto groundnut shell. Appl Water Sci 9(4):1-11. https://doi.org/10.1007/s13201-019-0987-8

Cimino G, Passerini A, Toscano G (2000) Removal of toxic cations and $\mathrm{Cr}(\mathrm{VI})$ from aqueous solution by hazelnut shell. Water Res. https://doi.org/10.1016/S0043-1354(00)00048-8

Dada A, Olalekan A, Olatunya A, Dada O (2012) Langmuir, Freundlich, Temkin and Dubinin - Radushkevich Isotherms studies of equilibrium sorption of $\mathrm{Zn}$ (II) unto phosphoric acid modified rice husk. IOSR J Appl Chem 3(1):38-45. https://doi. org/10.9790/5736-0313845

Dilekoglu MF (2016) Use of genetic algorithm optimization technique in the adsorption of phenol on banana and grapefruit peels. J Chem Soc Pak 38(6):1252

Faisal M, Hasnain S (2004) Microbial conversion of $\mathrm{Cr}(\mathrm{VI})$ into $\mathrm{Cr}(\mathrm{III})$ in industrial effluent. Afr J Biotech. https://doi. org/10.4314/ajb.v3i11.15027

Foo K, Hameed B (2009) Insights into the modeling of adsorption isotherm systems.pdf. Chem Eng J 156:2-10

Futalan CM, Tsai WC, Lin SS, Hsien KJ, Dalida ML, Wan MW (2012) Copper, nikel and lead adsorption from aqueous solution using chitosan-immobilized on bentonite in ternary system. Sustain Environ Res 22(6):345-355

Garba ZN, Bello I, Galadima A, Lawal AY (2016) Optimization of adsorption conditions using central composite design for the removal of copper(II) and lead(II) by defatted papaya seed. Karbala Int J Mod Sci 2(1):20-28. https://doi.org/10.1016/j.kijom s.2015.12.002

Gottipati R, Ecocarb G, Rourkela T (2012) Application of response surface methodology for optimization of $\mathrm{Cr}(\mathrm{III})$ and $\mathrm{Cr}(\mathrm{VI})$ adsorption on commercial activated. Res J Chem Sci 2:40-48

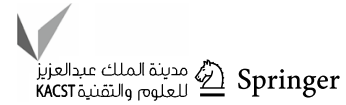


Ho Y (2006) Isotherms for the sorption of lead onto peat: comparison of linear and non-linear methods. Pol J Environ Stud 15(1):81-86

Icrist (2005) Crops gallery: groundnut. http://www.icrisat.org/text/ coolstuff/-crops/gcrops4.html

Juang RS, Wu F-C, Tseng R-L (1996) Adsorption isotherms of phenolic compounds from aqueous solutions onto activated carbon fibers. J Chem Eng Data 41(3):487-492. https://doi.org/10.1021/ je950238g

Khan A, Al-Haddad IAW (1996) Generalized equation for adsorption isotherms for multi-component organic pollutants in dilute aqueous solution. Environ Technol 17:13-23

Lagergren S (1898) About the theory of so-called adsorption of soluble substance. K Sven Vetenskapsakad Handlingar Band 24:1-39

Lim AP, Aris AZ (2014) A review on economically adsorbents on heavy metals removal in water and wastewater. Rev Environ Sci Biotechnol 13(2):163-181. https://doi.org/10.1007/s1115 7-013-9330-2

Maximova A, Koumanova B (2008) Equilibrium and kinetics study of adsorption of basic dyes onto perfil from aqueous solutions. $\mathbf{J}$ Univ Chem Technol Metall 43(1):101-108

Mohammad YS, Igboro SB, Giwa A, Okuofu CA (2014) Modeling and optimization for production of rice husk activated carbon and adsorption of phenol. Hindawi Publ Corpor J Eng 201:1-10. https ://doi.org/10.1155/2014/278075

Mourabet M, El Rhilassi A, El Boujaady H, Bennani-Ziatni M, Taitai A (2017) Use of response surface methodology for optimization of fluoride adsorption in an aqueous solution by Brushite. Arab J Chem 10:S3292-S3302. https://doi.org/10.1016/j.arabj c. 2013.12.028

Oboh I, Aluyor E, Audu T (2009) Biosorption of heavy metal ions from aqueous solutions using a biomaterial. Leonardo J Sci Iss 14(14):58-65

Ofudje EA, Akiode OK, Oladipo GO, Adedapo AE, Adebayo LO, Awotula AO (2015) Application of raw and alkaline-modified coconut shaft as a biosorbent for $\mathrm{Pb}^{2+}$ removal. BioResources 10(2):3462-3480. https://doi.org/10.15376/biores.10.2.3462-3480

Okuofu CA, Osakwe C (2012) Comparative analysis of the adsorption of heavy metals in wastewater using Borrassus Aethiopium and Cocos Nucifera. Int J Appl 2(7):314-322

Osakwe CE, Sanni I, Sa'id S, Zubairu A (2014) Adsorption of heavy metals from wastewaters using Adonosia digitata fruit shells and Theobroma cacao pods as adsorbents: a comparative study. AU J Technol 18(1):11-18
Owolabi RU, Usman MA, Kehinde AJ (2018) Modelling and optimization of process variables for the solution polymerization of styrene using response surface methodology. J King Saud Univ Eng Sci 30(1):22-30. https://doi.org/10.1016/j.jksues.2015.12.005

Owusu-adjei E, Baah-mintah R, Salifu B (2017) Analysis of the groundnut value chain in Ghana. World J Agric 5(3):177-188. https://doi.org/10.12691/wjar-5-3-8

Pandey A, Bera D, Shukla A, Ray L (2007) Studies on Cr(VI), Pb(II) and $\mathrm{Cu}(\mathrm{II})$ adsorption-desorption using calcium alginate as biopolymer. Chem Speciat Bioavailab 19(1):17-24. https://doi. org/10.3184/095422907X198031

Park S, Jung WY (2001) Removal of chromium by activated carbon fibers plated with copper metal. Carbon Sci 2(1):15-21

Saer GW (1956) Determination of specific surface area of sodium hydroxide. Anal Chem 28(2):1981-1983

Sellscope J (1962) Cowpea (Vignaunguiculata L Walp). Field Crop Abstract 15:259-266

Shawabkeh RA, Tutunji MF (2003) Experimental studies and modeling of the basic dye sorption by diamaceous clay. Appl Clay Sci 24:111-114

Sud D, Mahajan G, Kaur MP (2008) Agricultural waste material as potential adsorbent for sequestering heavy metal ions from aqueous solutions—a review. Biores Technol. https://doi.org/10.1016/j. biortech.2007.11.064

Toth J (1971) State equations of solid-gas interface layers. Acta Chimica Academiae Scientarium Hungaricae 69(3):311-318

Yu X, Zhang G, Xie C, Yu Y, Cheng T, Zhou Q (2011) Equilibrium, kinetic, and thermodynamic studies of hazardous dye neutral red biosorption by spent corncob substrate. BioResources 6(2):936-949

Yusuff AS (2018) Optimization of adsorption of Cr(VI) from aqueous solution by Leucaena leucocephala seed shell activated carbon using design of experiment. Appl Water Sci 8(8):1-11. https:// doi.org/10.1007/s13201-018-0850-3

Zarubica A, Purenovic M (2011) Biosorptive removal of $\mathrm{Pb}^{2+}, \mathrm{Cd}(\mathrm{II})$ and $\mathrm{Zn}(\mathrm{II})$ ions from water by Lagenaria vulgaris shell. WaterSA 37(3):303-312

Publisher's Note Springer Nature remains neutral with regard to jurisdictional claims in published maps and institutional affiliations. 